\title{
SCAN ANGLE IMPACT ON LIDAR-DERIVED METRICS USED IN ABA MODELS FOR PREDICTION OF FOREST STAND CHARACTERISTICS : A GRID BASED ANALYSIS
}

\author{
K. R. Dayal ${ }^{1 *}$, S. Durrieu ${ }^{1}$, S. Alleaume ${ }^{1}$, F. Revers ${ }^{2}$, E. Larmanou ${ }^{1}$, J-P Renaud ${ }^{3}$, M. Bouvier ${ }^{4}$ \\ ${ }^{1}$ INRAE, TETIS, Université de Montpellier, AgroParisTech, CIRAD, CNRS, INRAE, Montpellier, France \\ 2 INRAE, UMR 1202 BIOGECO, Université de Bordeaux, Cestas, France \\ ${ }^{3}$ Office National des Forêts, Nancy, France \\ ${ }^{4}$ INFOGEO, Montpellier, France
}

(karun.dayal, sylvie.durrieu, samuel.alleaume, eric.larmanou, frederic.revers)@inrae.fr

jean-pierre.renaud-02@onf.fr

marc.bouvier@infogeo.xyz

Commission III, WG III/10

KEY WORDS: lidar, scan-angle, area-based approach, forest metrics, forest inventory, light

\begin{abstract}
Lidar scan angle can affect estimation of lidar-derived forest metrics used in area-based approaches (ABAs). As commonly used first-order metrics and various user-developed metrics are computed in the form of a grid or a raster, their response to various scan angles needs to be investigated similarly. The objective of this study was to highlight the impact of scan angles on 11 metrics ( 9 height-based and 2 other commonly used metrics) at the level of the grid-cell. The study area was divided into a grid of cell size $30 \mathrm{~m}$. In every grid-cell, the flight lines that sampled at least $90 \%$ area of the grid-cell were identified. The flight lines and the corresponding point clouds were then classified based on their mean scan angle into four classes $0^{\circ}-10^{\circ}, 10^{\circ}-20^{\circ}, 20^{\circ}-30^{\circ}$ and $30^{\circ}$ $40^{\circ}$. Metrics were computed for one flight line per class for each grid-cell. This resulted in a maximum of four values for a metric in every grid-cell. Comparing these values revealed the evolving nature of the metrics with the scan angle. For the comparison we used a paired t-test and simple linear regression. We observed that most of the metrics were systematically under-estimated with increasing scan angle. Gap-fraction, rumple index were affected more than standard deviation of height while the maximum height was relatively stable. Among the height percentiles, the higher percentiles were relatively more stable compared to the lower percentiles. Scan angles can indeed have an impact on the estimation of lidar derived metrics. Although, many of the metrics studied showed statistically significant differences in their computation for different scan angles, their impact on the accuracies of ABA models needs to be studied further by accounting for the differences as shown in this study.
\end{abstract}

\section{INTRODUCTION}

Lidar acquires an explicit three-dimensional representation of the forest structure. Such information is essential to model both ecological and resource management information, and there is a broad spectrum of methods, across various airborne LiDAR platforms, for improved characterisation of forest ecosystems and a better understanding of their functioning. It is possible to extract several forest inventory attributes with improved accuracies for better resource management (Bohn \& Huth, 2017; Breidenbach et al., 2010; Côté et al., 2018; Næsset, 2007; Wallace et al., 2012). Lidar data can also be used to assess biophysical variables, such as above-ground biomass (AGB) and Leaf Area Index (Bouvier et al., 2015; Breidenbach \& Astrup, 2012; Lefsky et al., 2002; Vincent et al., 2017)

In Area-based approaches (ABAs), a set of ALS variables $\left(\mathrm{X}_{\mathrm{i}}\right)$ derived from lidar data for a given area - is linked to a target variable $(\mathrm{Y})$ measured at the same area on the ground (White et al., 2017). This is done for a handful of different plots to build a predictive model to predict the target variable for the entire forest. The fundamental unit of a predictive model is a small subset from the lidar point cloud, the area of which equals the area of a reference field plot (i.e., typically 0.025 to 0.07 ha). A model developed for representative plots is then applied to the whole forest area divided into grid cells, the area of which still equals the area of reference field plots. Any given target forest attribute is thus predicted at the cell level. Notwithstanding the trade-off between area coverage, the density, and the resolution of measurements between different platforms (i.e. aerial and unmanned aerial vehicles (UAV)), studies have recommended further investigation of variation in acquisition parameters for forest parameter assessment (Cao et al., 2016; Korhonen et al., 2011; Tompalski et al., 2019). Some studies focussed on the effect of point density on the accuracy of stand attribute predictions (Bouvier et al., 2019; Næsset, 2009; Singh et al., 2016). Relevant lidar metrics selected to build predictive models were found to differ significantly with pulse density in Næsset, (2009) but in Bouvier et al., (2019) there was no change in the four metrics used. However, in the range of explored pulse densities, i.e. from 0.06 to $12.7 \mathrm{pulses} / \mathrm{m}^{2}$, in all the studies considered together, only minor or even no impact on stand attribute predictions was found.

Another critical acquisition parameter is the maximum off-nadir scan angle (Bater et al., 2011). Liu et al., (2018) demonstrated the effect of scan angle on gap fraction estimation which, in turn, affects the estimation of LAI. Tompalski et al., (2019) recommend the disentangling of various acquisition parameters, including scan angle, to develop robust transferable models. Studies utilising lidar-based metrics generally do not consider the influence of scan angles, and there may be unaccounted biases

Corresponding author 
which may cancel each other in predictive models (Roussel et al., 2018). There can only be one, or a few flight-passes for a given area, and it is evident that the 'viewing configuration', or the scan angle with which each grid-cell is sampled will be different (Figure 1). Owing to these inconsistencies, metrics computed for an entire forest, in the form of a raster may possess inherent biases. For airborne acquisitions, Evans et al., (2009) recommend limiting the maximum scan angle to $15^{\circ}$ to reduce measurement errors, despite a reduction in flight time and cost that would have enabled higher scan angles. In Montaghi, (2013), several metrics were found to be relatively stable up to an angle of 20 degrees. However, with the increasing popularity of light systems embedded on low altitude platform - such as ULM or UAVs - it is imperative to understand the response of various commonly used metrics to varying scan angles as limiting the scan angle to 15-20 degrees is hardly feasible in an operational mode for reasons of time and data volume optimisation. This would allow for better management of the biases and result in more informed mission planning for efficient data acquisition.

In the present study, with the objective to contribute to the understanding of how scan angles modify metrics that are commonly used in ABA approaches, we analysed the impact of scan angles on a set of metrics that can be used to describe the horizontal and vertical vegetation structure of a riparian forest located in the Landes area, in south-west France.

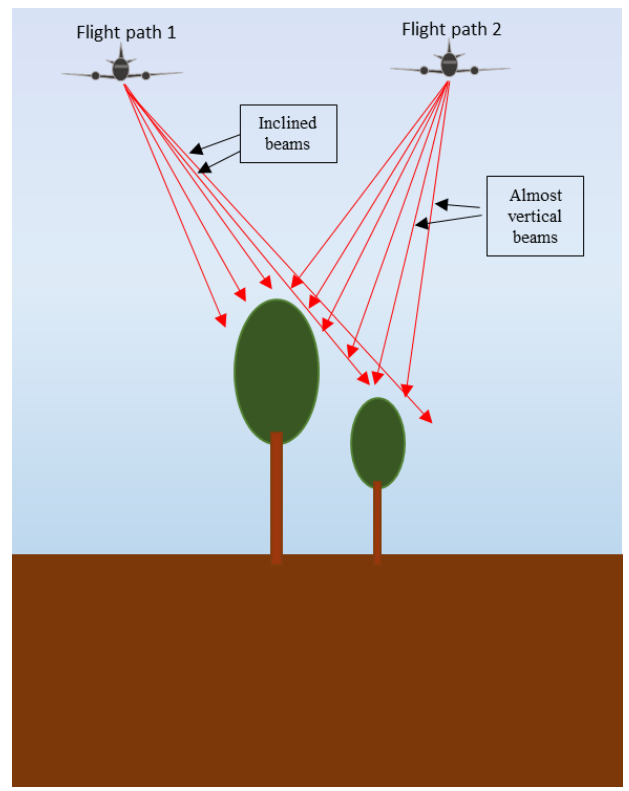

Figure 1: Acquisition geometry from different flight lines

\section{MATERIALS}

\subsection{Study area}

The study area is a riparian zone bordered by pine forests in the Ciron valley in the southeast of the Gironde and the northwest of the Lot-et-Garonne departments, in the Aquitaine region of south-western France. As a result of related projects, field plot information was available for 30 circular sites ( $15 \mathrm{~m}$ radius) along the river Ciron (flowing in SE-NW direction) and its tributaries, covering a total length of approximately $45 \mathrm{~km}$. The plots are representative of the riparian ecosystem. The field measurements are indicative of structurally diverse vegetation in the region, with as many as 33 different species of trees and a diameter at breast height (DBH) varying from $7.5 \mathrm{~cm}$ to $87 \mathrm{~cm}$ ( Figure 2). The riparian region includes the active floodplains. It is highly biodiverse because of sparse forest management activities. In contrast, periodic management practices are carried out in the pine forests located beyond the riparian region.

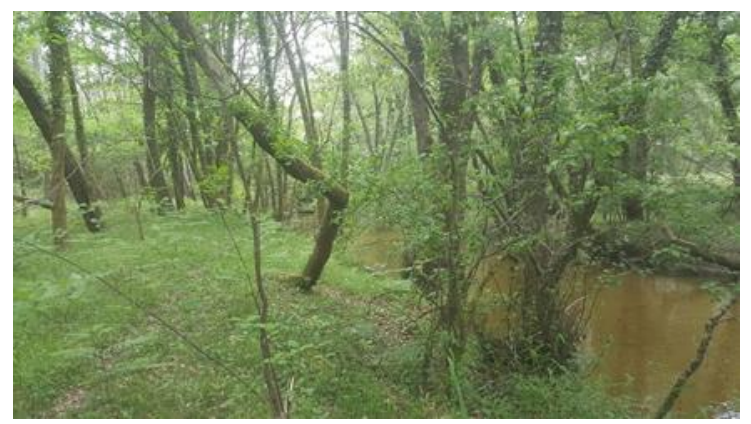

Figure 2: Example of the riparian environment in the study area

\subsection{Lidar data}

In early October 2019, INFOGEO (France) acquired lidar data using a VQ580 laser scanner (RIEGL, Austria) on an ultralight aircraft platform. The flying altitude was approximately $250 \mathrm{~m}$, which enabled data-acquisition at an overall point density of around $68 \mathrm{pts} / \mathrm{m}^{2}$. Overlap of 35\%-40\% and several passes over any given area (Figure 3) ensured that several locations across the region were sampled with multiple 'viewing' configurations (Figure 1). However, it was not possible to obtain all the configurations for all the areas. Additional sensor specifications are available in Table1. Data pre-processing was carried out by INFOGEO, which involved classification of ground points using TerraScan (Terrasolid Ltd., Finland).

\begin{tabular}{|c|c|}
\hline Date of acquisition & Early October 2019 \\
\hline Sensor & RIEGL VQ580 \\
\hline Wavelength & Near-infrared \\
\hline Field of view & $60^{\circ}\left(+30^{\circ} /-30^{\circ}\right)$ \\
\hline Beam divergence & $0.2 \mathrm{mrad}$ \\
\hline Footprint diameter & $52 \mathrm{~mm} @ 250 \mathrm{~m}$ \\
\hline Ground speed & $25 \mathrm{~m} / \mathrm{s}$ \\
\hline Point density & $68 \mathrm{pts} / \mathrm{m}^{2}$ \\
\hline Flight altitude AGL & $250 \mathrm{~m}$ \\
\hline
\end{tabular}

Table 1: Technical specifications of the sensor

\section{METHODS}

\subsection{Metrics selection}

While new metrics are continually being developed to improve prediction of forest attributes (Almeida et al., 2019; Bouvier et al., 2015; Véga et al., 2016), first order derivatives such as heightbased and density-based metrics are commonly utilised in ABA approaches (Mitchell et al., 2012). We thus considered heightbased metrics such as mean, maximum, standard deviation, coefficient of variation of heights, and height percentiles $\left(10^{\text {th }}\right.$, $30^{\text {th }}, 50^{\text {th }}, 70^{\text {th }}$ and $\left.90^{\text {th }}\right)$. When computing these metrics, the understory vegetation and ground points were not considered by filtering out all points below a height threshold of $1 \mathrm{~m}$. Besides typically describing distributions (Roussel et al., 2018), these 


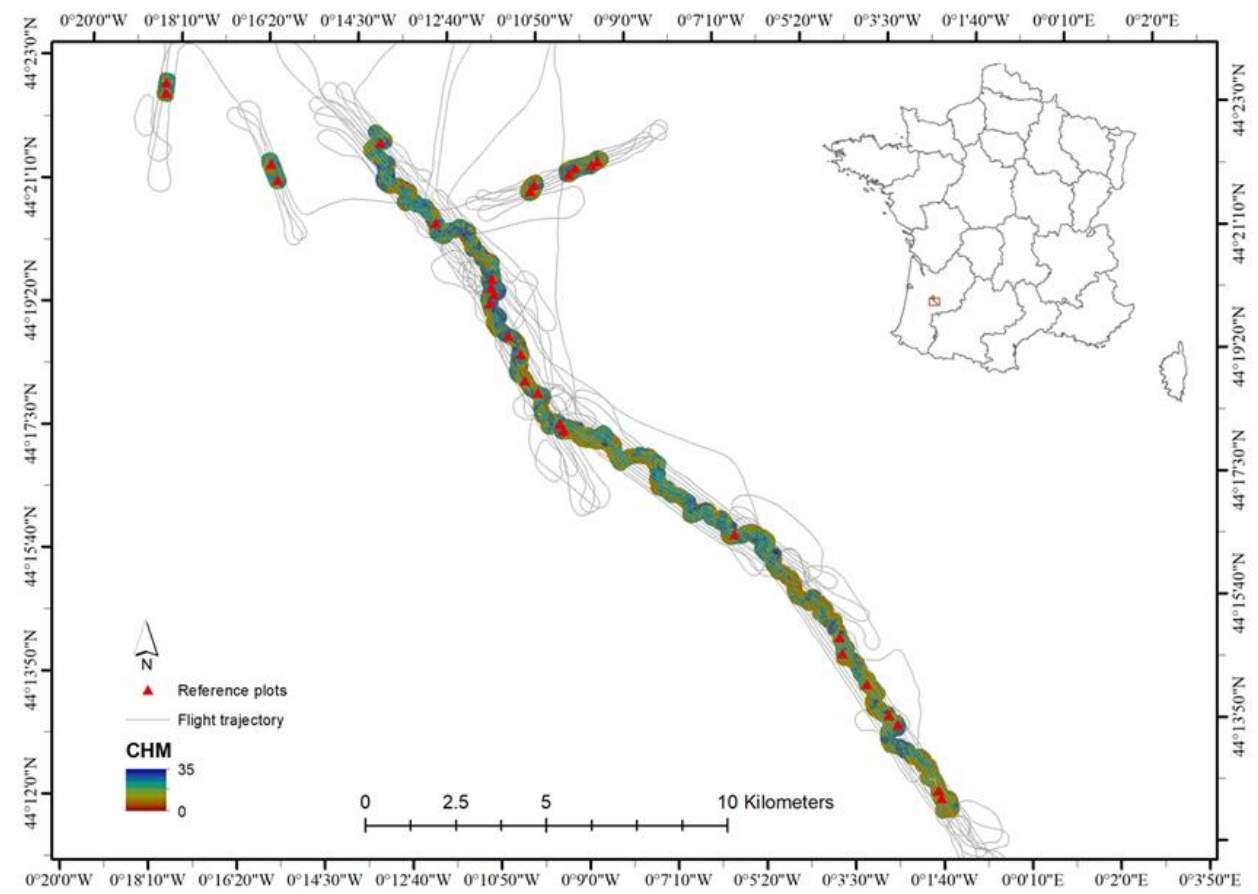

Figure 3: Canopy height model of the Ciron valley area with field plot locations and data acquisition flight lines

metrics are also considered to be descriptors of forest structural conditions.

We also included two other widely studied metrics in our study: gap fraction and rumple index. The distribution of foliage determines the proportion of open areas in forest vegetation, which, in turn, determines the amount of energy from the sun and the sky that travels through the canopy (Nilson, 1971). Gap frequency or gap fraction is a good indicator of the structural characteristics of the vegetation and can be assessed from lidar data (Bouvier et al., 2015). Gap fraction was calculated as described by Bouvier et al., (2015) by dividing the number of first returns below a specific reference height $(2 \mathrm{~m})$ by the total number of first returns. Rumple index is the ratio of the outer surface area of the canopy to the ground surface (Parker \& Russ, 2004). It is a measure of the structural complexity of the stand. It characterises the outer-canopy, which is related to the development of the forest stand.

\subsection{Data preparation to analyse effects of scan angle}

As stated in the introduction, the grid-cell is the unit area used to apply an ABA model. The dimensions of the grid-cell are similar to those of field reference plots, which are $30 \mathrm{~m}$ diameter circular plots in this study. Hence, we attempted to discretise the scan angles according to a grid containing cells of $30 \mathrm{~m} \times 30 \mathrm{~m}$ and analysed the point cloud in every cell to understand the impact of variations in scan angle on pre-defined metrics. Due to the acquisition geometry as illustrated is Figure 1, not every grid-cell is sampled with all the possible scan angles. In other words, the data with continuous scan angles, i.e. $1^{\circ}, 2^{\circ}, 3^{\circ} \ldots 10^{\circ}, 11^{\circ}$ etc. is not available for every grid-cell. Five classes of scan angle (absolute value) were thus defined based on the scan angle rank of the LAS dataset, namely $0^{\circ}-10^{\circ}$ as class $1,10^{\circ}-20^{\circ}$ as class $2,20^{\circ}-30^{\circ}$ as class $3,30^{\circ}-40^{\circ}$ as class 4 and $>40^{\circ}$ as class 5 . The scan angle is based on 0 degrees for nadir and $-90^{\circ}$ and $+90^{\circ}$ to the left and right sides of the aircraft respectively (ASPRS, 2013). We hypothesised that, for each pair of scan-angle classes (class 1-class 2, class 1-class 3 etc.), the number of common grid-cells sampled from the five different classes of angle would be sufficiently high and representative of the diversity of the stand types present across the site.

The steps of the process followed are: (i) for each grid-cell, we identified all the flight lines from which the lidar sensor sampled it either entirely or partially, and divided the point cloud in the grid-cell into subsets based on the flight lines. We did not consider any flight lines and, by extension, point clouds that partially sampled a grid-cell if they covered less than $90 \%$ of its area to avoid including in the analysis metrics that are not representative of the whole forest plot within the grid-cell; (ii) we then computed the mean scan angle for each of the remaining point clouds. We assumed that from a particular flight line and at a flight height of $250 \mathrm{~m}$, the sensor samples a given grid-cell largely homogeneously and that the mean scan angle could be considered representative of the acquisition characteristics. This assumption was necessary for the sake of simplification, as it is not possible to analyse the influence of scan angle continuously. In practical applications, all regions are not sampled equally with all scan angles, i.e. the laser beams are never parallel. When a grid-cell was viewed with the same scan-angle class from more than one flight line, we considered the flight line that had mean scan angles closest to the respective class median values $\left(0^{\circ}\right.$ for $10^{\circ}$ to $+10^{\circ}, 15^{\circ}$ for $10^{\circ}$ to $20^{\circ}$ etc.); (iii) the metrics were computed for the point clouds from each of the remaining flight lines. After considering the area threshold of $90 \%$, there were instances where some classes had no flight lines/point clouds and in such cases, the metrics were not calculated.

The result comprised a stack of five rasters in which every gridcell had a vector of five values for the metrics, one for each class of scan angle (including NA values for empty classes). During the data acquisition, a certain buffer area was considered on either side of the riparian forests. These areas contained urban settlements and agricultural fields. We used a $95^{\text {th }}$ height 


\begin{tabular}{|c|c|c|c|c|c|c|c|c|c|}
\hline \multirow{2}{*}{ Metric } & \multicolumn{3}{|c|}{ Mean differences } & \multicolumn{3}{|c|}{ Standard deviation of differences } & \multicolumn{3}{|c|}{ (Intercept, Slope) } \\
\hline & $\mathrm{cll}-\mathrm{cl} 2$ & $\mathrm{cll}-\mathrm{cl} 3$ & $\mathrm{cll}-\mathrm{cl} 4$ & $\mathrm{cll}-\mathrm{cl} 2$ & $\mathrm{cll}-\mathrm{cl} 3$ & cll - cl 4 & $\mathrm{cl} 2 \sim \mathrm{cll}$ & $\mathrm{cl} 3 \sim \mathrm{cll}$ & $\mathrm{cl} 4 \sim \mathrm{cll}$ \\
\hline $\operatorname{Max}(\mathbf{m})$ & -0.001 & 0.014 & $\begin{array}{c}0.183 \\
\text { 水水 }\end{array}$ & 0.563 & $\begin{array}{c}0.575 \\
(+2.1 \%)\end{array}$ & $\begin{array}{c}0.903 \\
(+60.4 \%)\end{array}$ & $(0.1,1)$ & $\begin{array}{c}(0.19,0.99) \\
\text { 水水 }\end{array}$ & $\begin{array}{c}(0.21,0.98) \\
\text { 水水 }\end{array}$ \\
\hline Mean (m) & $\begin{array}{c}0.113 \\
\text { 水水 }\end{array}$ & $\begin{array}{c}0.130 \\
\text { 水水 }\end{array}$ & 0.030 & 0.453 & $\begin{array}{c}0.547 \\
(+20.8 \%) \\
\end{array}$ & $\begin{array}{c}0.864 \\
(+90.7 \%) \\
\end{array}$ & $\begin{array}{c}(0.02,0.99) \\
\text { 水水 }\end{array}$ & $\begin{array}{c}(0.13,0.98) \\
\text { 水水 }\end{array}$ & $\begin{array}{c}(0.33,0.97) \\
\text { 水水 }\end{array}$ \\
\hline sd (m) & 0.010 & $\begin{array}{c}0.035 \\
\text { 水水 }\end{array}$ & $\begin{array}{c}0.103 \\
\text { 水水 }\end{array}$ & 0.258 & $\begin{array}{c}0.326 \\
(+26.4 \%)\end{array}$ & $\begin{array}{c}0.447 \\
(+73.3 \%)\end{array}$ & $\begin{array}{c}(0.25,0.95) \\
\text { 水水 }\end{array}$ & $\begin{array}{c}(0.3,0.94) \\
\text { 水水 }\end{array}$ & $\begin{array}{c}(0.38,0.91) \\
\text { *水水 }\end{array}$ \\
\hline cv (m) & $\begin{array}{c}-0.187 \\
* *\end{array}$ & 0.008 & $\begin{array}{c}0.869 \\
\text { 水* }\end{array}$ & 2.625 & $\begin{array}{c}3.418 \\
(+30.2 \%) \\
\end{array}$ & $\begin{array}{c}4.919 \\
(+87.4 \%) \\
\end{array}$ & 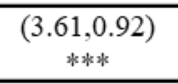 & $\begin{array}{c}(4.59,0.9) \\
\text { 水* }\end{array}$ & $\begin{array}{c}(5.24,0.86) \\
\text { *水水 }\end{array}$ \\
\hline p10 (m) & $\begin{array}{c}0.176 \\
\text { 水水 } \\
\end{array}$ & $\begin{array}{c}0.147 \\
\text { 水* } \\
\end{array}$ & -0.025 & 0.971 & $\begin{array}{c}1.198 \\
(+23.4 \%) \\
\end{array}$ & $\begin{array}{c}1.628 \\
(+67.7 \%) \\
\end{array}$ & 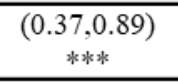 & $\begin{array}{c}(0.57,0.85) \\
\text { 水* } \\
\end{array}$ & $\begin{array}{c}(0.96,0.81) \\
\text { 水*k }\end{array}$ \\
\hline p30 (m) & $\begin{array}{l}0.104 \\
\text { 水水 }\end{array}$ & $\begin{array}{c}0.090 \\
* *\end{array}$ & $\begin{array}{c}-0.121 \\
*\end{array}$ & 0.993 & $\begin{array}{c}1.347 \\
(+35.6 \%)\end{array}$ & $\begin{array}{c}2.113 \\
(+112.8 \%)\end{array}$ & $\begin{array}{c}(0.34,0.96) \\
\text { 水水 }\end{array}$ & 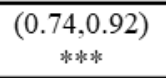 & $\begin{array}{c}(1.56,0.86) \\
\text { 水* }\end{array}$ \\
\hline p50 (m) & $\begin{array}{c}0.130 \\
\text { 水水 }\end{array}$ & $\begin{array}{c}0.159 \\
\text { 水水 } \\
\end{array}$ & 0.051 & 0.620 & $\begin{array}{c}0.879 \\
(+41.8 \%) \\
\end{array}$ & $\begin{array}{c}1.217 \\
(+96.3 \%) \\
\end{array}$ & $\begin{array}{c}(0.07,0.99) \\
\text { 水水 } \\
\end{array}$ & $\begin{array}{c}(0.2,0.97) \\
\text { *水水 }\end{array}$ & $\begin{array}{c}(0.5,0.96) \\
\text { 水水 } \\
\end{array}$ \\
\hline p70 (m) & $\begin{array}{l}0.123 \\
\text { 水水 } \\
\end{array}$ & $\begin{array}{l}0.153 \\
\text { 水水 } \\
\end{array}$ & $\begin{array}{c}0.102 \\
\text { 水水 } \\
\end{array}$ & 0.541 & $\begin{array}{c}0.715 \\
(+32.2 \%) \\
\end{array}$ & $\begin{array}{c}0.813 \\
(+50.3 \%) \\
\end{array}$ & $\begin{array}{c}(0.01,0.99) \\
\text { 水水水 } \\
\end{array}$ & $\begin{array}{c}(0.11,0.98) \\
\text { 水水水 }\end{array}$ & $\begin{array}{c}(0.18,0.98) \\
\text { 水水 }\end{array}$ \\
\hline p90 (m) & $\begin{array}{c}0.089 \\
\text { 水水 }\end{array}$ & $\begin{array}{c}0.122 \\
\text { 水水 }\end{array}$ & $\begin{array}{c}0.132 \\
\text { 水水水 }\end{array}$ & 0.518 & $\begin{array}{c}0.663 \\
(+28.0 \%)\end{array}$ & $\begin{array}{c}0.827 \\
(+59.7 \%)\end{array}$ & $\begin{array}{c}(-0.01,1) \\
\text { 水水 }\end{array}$ & $\begin{array}{c}(0.08,0.99) \\
\text { 水水 }\end{array}$ & $\begin{array}{c}(0.2,0.98) \\
\text { 水水 }\end{array}$ \\
\hline rumple ${ }^{\#}$ & $\begin{array}{c}-2.269 \\
\text { 水*k } \\
\end{array}$ & -0.206 & $\begin{array}{c}5.394 \\
\text { 水水 }\end{array}$ & 4.757 & $\begin{array}{c}5.143 \\
(+8.1 \%) \\
\end{array}$ & $\begin{array}{c}7.102 \\
(+49.3 \%) \\
\end{array}$ & $\begin{array}{c}(3.94,0.93) \\
\text { 水* }\end{array}$ & $\begin{array}{c}(5.13,0.8) \\
\text { 水水 }\end{array}$ & $\begin{array}{c}(5.86,0.54) \\
\text { 水水 }\end{array}$ \\
\hline $\begin{array}{c}\text { gap- } \\
\text { fraction }^{\#}\end{array}$ & $\begin{array}{l}0.029 \\
\text { 水水 }\end{array}$ & $\begin{array}{l}0.050 \\
\text { 水水 }\end{array}$ & $\begin{array}{l}0.079 \\
\text { 水水 }\end{array}$ & 0.038 & $\begin{array}{c}0.051 \\
(+34.2 \%)\end{array}$ & $\begin{array}{c}0.079 \\
(+107.9 \%) \\
\end{array}$ & $\begin{array}{c}(-0.01,0.94) \\
\text { 水水水 }\end{array}$ & $\begin{array}{c}(-0.02,0.89) \\
\text { 水水 } \\
\end{array}$ & $\begin{array}{c}(-0.03,0.82) \\
\text { 水水 }\end{array}$ \\
\hline
\end{tabular}

Table 2: Tabulation of the paired t-tests, standard deviation of differences (with the increase relative to cl1-cl2 in \% in parenthesis) and joint hypothesis tests for the intercept $=0$ and slope $=1$ scenario; $\mathrm{cl} 1, \mathrm{cl} 2, \mathrm{cl} 3, \mathrm{cl} 4$ are short for classes $1,2,3$ and 4 respectively. (\#=unitless, $* * *=<0.001, * *=<0.01, *=<0.05, .=<0.1,{ }^{\prime}$ ' $=>0.1$ )

percentile raster to conditionally filter out all the pixels in the five layers corresponding to a $95^{\text {th }}$ percentile value of $7 \mathrm{~m}$ or less. The number of grid-cells with points belonging to class $5\left(40^{\circ}-50^{\circ}\right)$ were significantly lower compared to other classes. We also observed that these grid-cells were in regions where the aircraft was making a turn during data acquisition. Therefore, we did not consider class 5 and conducted further analysis of the other four classes. After dropping class 5 and retaining only grid-cells corresponding to forests $\left(95^{\text {th }}\right.$ height percentile $\left.>7 \mathrm{~m}\right)$ we first analysed the diversity of viewing configurations that could be found on the area by counting the number of scan angle classes per grid-cell. Then, metrics were compared for grid-cells viewed concurrently from the first four classes of scan angles. 2000 common grid-cells distributed across the entire study area were available.

\subsection{Analysis of scan angle effects on the selected metrics}

For a statistical understanding of the influence of scan angle on metrics, we compared the distribution of metrics using mean and standard deviation. We used the paired sample t-test or dependent sample t-test to determine whether the mean difference between two sets of observations is zero. In a paired sample t-test, each subject or entity is measured twice, resulting in pairs of observations. We compared the metric values for class 2 , class 3 and class 4 to class 1 values. The null hypothesis $\left(H_{0}\right)$ being that the true mean difference $\left(\mu_{d}\right)$ between the classes is equal to zero. The two tailed alternative hypothesis $\left(H_{1}\right)$ assumes that the true mean difference $\left(\mu_{d}\right)$ is not zero. The level of significance was 0.05 . The dispersions of differences between class 1 and class $i$ $(\mathrm{i}=\{2,3,4\})$ were also assessed by computing the standard deviations of the cell by cell differences for each pair of scanangle classes considered.
Furthermore, we also compared the metric values for each of classes 2, 3 and 4 to class 1 using simple linear regression to assess the impact of scan angle as we move away from a predominantly vertical 'viewing conditions' (class 1 ). The linear relationships were tested for statistical significance in two aspects, namely, slope and intercept. The equation for the linear regression model that can be used to explain the relation between $Y$ (class i, where $\mathrm{i}=\{2,3,4\})$ and $x$ (class 1 ) is as follows:

$$
Y=\beta_{0}+\beta_{1} x+\epsilon
$$

$\beta_{0}$ is the coefficient for intercept and $\beta_{1}$ is the coefficient for the slope. Using the linearHypothesis() function in $\mathrm{R}$, we jointly tested for the significance of $\beta_{0}=0$ and $\beta_{1}=1$, at a level of significance of 0.05 . For $P$-values $<0.05$, the null hypotheses were rejected, thereby indicating that there was a bias in the estimation of the metrics for higher scan angles, either due to the slope or the intercept.

\section{RESULTS}

\subsection{Summary of the grid-cells}

There were 16758 grid-cells with a $95^{\text {th }}$ height percentile value of $7 \mathrm{~m}$ or more considered as forest. Among these, 2446 gridcells did not return any class of scan angles; 906 grid-cells contained any one class; 4549 grid-cells contained any two classes; 6857 grid-cells contained any three classes; and 2000 grid-cells contained four classes.

\subsection{Mean differences and standard deviation}

The results of the paired t-tests for the sample of 2000 grid-cells containing the four scan-angle classes are presented in Table 2. 

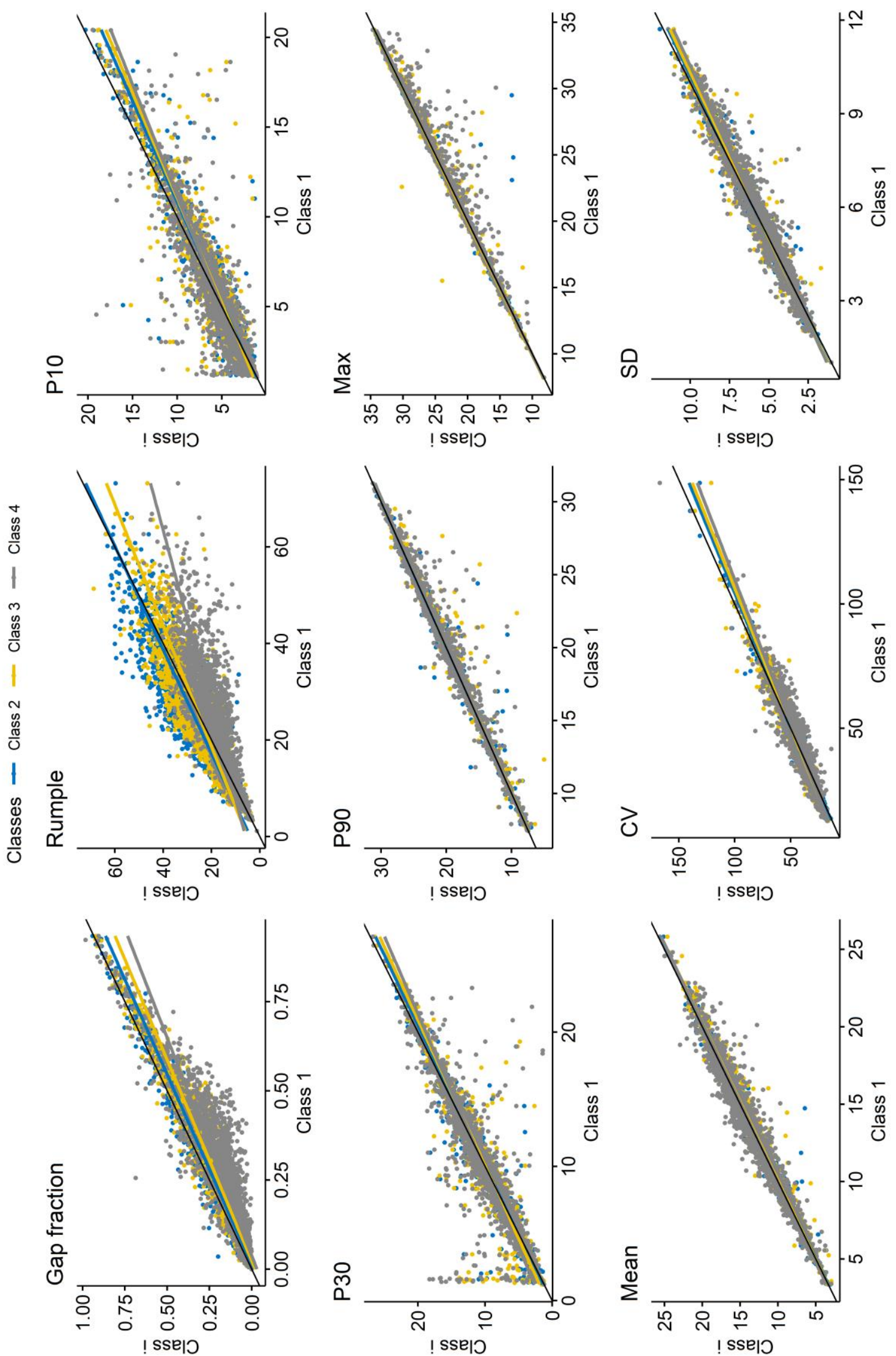

Figure 4: Scatter plots for selected metrics that depict the evolution of the metric under the influence of scan angle. 
As per the mean differences, for almost every metric there was an underestimation for the inclined classes, which led to statistically significant differences as shown in the table. The max (maximum) metric was not significantly affected across class 1 , class 2 and class 3; however, class1-class 4 was statistically significant with a mean difference of $0.183 \mathrm{~m}$. For the mean metric, the mean differences for class 1-class 2 and class 1-class 3 are statistically significant at $0.113 \mathrm{~m}$ and $0.130 \mathrm{~m}$ respectively. In the case of coefficient of variation of height and rumple index, the metrics for class 2 seem to have been overestimated compared to the reference class (class 2>class 1). There was no difference between class 1 and class 3 and a significant underestimation for class 4 compared to class 1 .

For coefficient of variation, the mean difference for class 1-class 4 was approximately $0.869 \mathrm{~m}$. The mean differences for the percentiles were mostly positive (ranging from 0.09 to 0.18 ) for class 1 -class 2 and class 1 -class 3 . The lower percentiles had no significant mean difference for class 1 -class 4 , with the exception of $\mathrm{p} 30\left(30^{\text {th }}\right.$ percentile $)$, which had a p-value of around 0.02 . Within the percentiles, for class 1-class 2 and class 1-class 3, p10 had the highest mean difference and the $\mathrm{p} 90\left(90^{\text {th }}\right.$ percentile) had the lowest mean difference. For any given metric, the standard deviations of the differences had an increasing trend from class 1-class 2 to class 1 -class 4 . This was observed for all metrics with no exception.

\subsection{Simple linear regression (cli $\sim$ cl1)}

A visual analysis of the scatterplots for class i vs class 1 showed that class 1 metrics are linearly related to the metrics of the other scan-angles. Figure 4 depicts the scatterplots for a subset of six metrics. Some metrics such as gap fraction and rumple index were clearly affected by the scan angle, while some such as p10 $\left(10^{\text {th }}\right.$ percentile) were affected to a lesser extent. The effect of scan angle on mean, max (maximum), and p90 is relatively lesser. Testing how different the regression lines are from the $y=x$ line can reveal the existence of systematic (intercept) and variable (slope) biases (Table 2). We observed that for almost every metric, the slopes of the respective regressions lines were less than one. For the height percentiles, between p10 to p90 there was a gradual shift of the regression lines towards the $y=x$. Lower percentiles were more affected by a change in scan-angle than higher percentiles. The null hypothesis, that slope $=1$ and intercept $=0$, was not rejected for the max metric for class $2 \sim$ class 1. Although the slope values for class $3 \sim$ class 1 and class $4 \sim$ class 1 are close to 1 , under the joint hypothesis test, the null hypothesis was not rejected due to a significant effect of the intercept. This was also the case for other metrics as shown in Table 2. Coefficient of variation, gap fraction, and rumple index appear to be considerably influenced by the scan angle either due to the existence of a significant systematic bias (CV and rumple index), or due to variable bias (gap fraction and rumple index).

\section{DISCUSSION}

The mean differences revealed the variations in metrics for different classes, but it could not adequately convey some of the biases (sometimes means are equal but can hide the existence of biases). On the other hand, simple linear regression was able to add to this information in two aspects. Firstly, as a visual diagnostic, it presented linear relationships between the classes for all the metrics. It also showed an increasing spread of the data as class 1 was compared with classes 2,3 , and 4 . This spread is responsible for the increase in the standard deviations of the differences as shown in Table 2. The rate of increase of the standard deviations are very high for the metrics (except max and rumple when comparing class 1-class 2 to class 1-class 3 ), with a percentage increase ranging between $+2 \%$ and $+42 \%$ and $+50 \%$ and $+112 \%$ when comparing class 1 -class 2 to class 1 -class 3 and to class 1-class 4, respectively. Secondly, the different slope and intercepts revealed the inherent biases in the estimation of these metrics from different scan angles. Rumple index and gap fraction were considerably affected which is significant as studies (Bouvier et al., 2015; Véga et al., 2016) have reported that these metrics were useful to improve models to predict forest parameters. Liu et al. (2018) observed that the scan angle affected the gap fraction differently in different forests (and different structural conditions). However, they did conclude that the estimation is maximum for vertical observation, i.e. nadir, which was also observed in this study.

The height based metrics were affected to a lesser extent. The max metric showed the least variation. The higher percentiles appeared to be relatively stable compared to the lower percentiles. Montaghi (2013) reported that the higher percentiles, in particular, remained relatively stable compared to density metrics (not explored in this study). They also said that the Understory ratio, defined as "the ratio between all returns below a given height (e.g., $2 \mathrm{~m}$ ) and the number of these returns plus returns classified as ground", was also affected by the scan angle. The computation of the understory ratio is similar to the calculation of the gap fraction in this study.

The variation in the estimation of metrics could potentially impact the quality of $\mathrm{ABA}$ models that utilise these metrics. Practical limitations in flight planning cause the grid-cells in an area to be sampled with different "viewing conditions". When several classes of angles are used together, changes in the metrics will also be due to differences in scan-angle and not only in stand characteristics. This effect could perhaps be systematically addressed by taking into account classes of scan angle when building models. For example, building one model for one class of scan angles which would necessitate more field plot measurements; or using regression analysis to model the effect of scan angle, with the possibility to partially correct for these effects before developing the model.

The limitations of the study are related to the generalisation of scan angles with mean scan angles in a range of $10^{\circ}$ to one class value. Within-class variations could not be addressed systematically. Moreover, even the mean scan angle for a flight line is a generalisation of range of scan angles. It is not possible to overcome these acquisition limitations. Furthermore, the characteristics of the stands could also have a significant role to play. This was however not addressed in the present study. It is pertinent that the intermingling of the effects of stand characteristics and scan angle be decoupled for a systematic appraisal. Radiative transfer based simulation of forest point clouds could open up potential avenues to address these issues.

\section{CONCLUSIONS}

In this study, we analysed metrics that are frequently used in ABA methods to understand their response to varying scan angles. Metrics were computed in the form of a grid for each class of 'viewing configuration,' i.e. scan angle. There was a noticeable impact on the metrics with gap fraction, rumple index, and CV of height being affected significantly. Higher height percentiles were affected to a lesser extent than lower height percentiles and the maximum height metric was relatively stable. The key advantage of ABA methods is the ability to characterise within-stand variability. This has been a proven development over the conventional stand-level based inventory (White et al., 
2017). However, practical data acquisition constraints may eventually lead to biases in metrics as demonstrated in this study. These biases can vary depending on the locations of the grid-cell and how they are sampled. The capacity to handle these biases could significantly contribute in improving the accuracy of the ABA models.

\section{ACKNOWLEDGEMENT}

This research was supported by CNES, the French Space Agency, within the framework of the FRISBEE TOSCA project (convention $\mathrm{n}^{\circ} 190337 / 00$ ) and by the GRAINE program of ADEME (Agence de l'Environnement et de la Maîtrise de l'Énergie) (PROTEST project, convention $\mathrm{n}^{\circ}$ 1703C0069). We also wish to acknowledge the financial support of Région Occitanie for the co-funding of K. Dayal's PhD grant (subvention $\mathrm{n}^{\circ}$ 2018001466/ALDOCT-000520).

\section{REFERENCES}

Almeida, D. R. A., Stark, S. C., Chazdon, R., Nelson, B. W., Cesar, R. G., Meli, P., Gorgens, E. B., Duarte, M. M., Valbuena, R., Moreno, V. S., Mendes, A. F., Amazonas, N., Gonçalves, N. B., Silva, C. A., Schietti, J., \& Brancalion, P. H. S. (2019). The effectiveness of lidar remote sensing for monitoring forest cover attributes and landscape restoration. Forest Ecology and Management, 438, 34-43. https://doi.org/10.1016/j.foreco.2019.02.002

ASPRS. (2013). LAS SPECIFICATION VERSION 1.4 - R13. 28.

Bater, C. W., Wulder, M. A., Coops, N. C., Nelson, R. F., Hilker, T., \& Nasset, E. (2011). Stability of Sample-Based ScanningLiDAR-Derived Vegetation Metrics for Forest Monitoring. IEEE Transactions on Geoscience and Remote Sensing, 49(6), 23852392. https://doi.org/10.1109/TGRS.2010.2099232

Bohn, F. J., \& Huth, A. (2017). The importance of forest structure to biodiversity-productivity relationships. Royal Society Open Science, 4(1), 160521. https://doi.org/10.1098/rsos.160521

Bouvier, M., Durrieu, S., Fournier, R. A., \& Renaud, J. P. (2015). Generalizing predictive models of forest inventory attributes using an area-based approach with airborne LiDAR data. Remote Sensing of Environment, 156, 322-334. https://doi.org/10.1016/j.rse.2014.10.004

Bouvier, M., Durrieu, S., Fournier, R. A., Saint-Geours, N., Guyon, D., Grau, E., \& de Boissieu, F. (2019). Influence of Sampling Design Parameters on Biomass Predictions Derived from Airborne LiDAR Data. Canadian Journal of Remote Sensing, 45(5), 650-672. https://doi.org/10.1080/07038992.2019.1669013

Breidenbach, J., \& Astrup, R. (2012). Small area estimation of forest attributes in the Norwegian National Forest Inventory. European Journal of Forest Research, 131(4), 1255-1267. https://doi.org/10.1007/s10342-012-0596-7

Breidenbach, J., Nothdurft, A., \& Kändler, G. (2010). Comparison of nearest neighbour approaches for small area estimation of tree species-specific forest inventory attributes in central Europe using airborne laser scanner data. European Journal of Forest Research, 129(5), 833-846. https://doi.org/10.1007/s10342-010-0384-1

Cao, L., Coops, N. C., Innes, J. L., Dai, J., Ruan, H., \& She, G. (2016). Tree species classification in subtropical forests using small-footprint full-waveform LiDAR data. International Journal of Applied Earth Observation and Geoinformation, 49, 39-51. https://doi.org/10.1016/j.jag.2016.01.007

Côté, J.-F., Fournier, R. A., Luther, J. E., \& van Lier, O. R. (2018). Fine-scale three-dimensional modeling of boreal forest plots to improve forest characterization with remote sensing. Remote Sensing of Environment, 219(4), 99-114. https://doi.org/10.1016/j.rse.2018.09.026

Evans, J. S., Hudak, A. T., Faux, R., \& Smith, A. M. S. (2009). Discrete return lidar in natural resources: Recommendations for project planning, data processing, and deliverables. Remote Sensing, 1(4), 776-794. https://doi.org/10.3390/rs1040776

Korhonen, L., Korpela, I., Heiskanen, J., \& Maltamo, M. (2011). Airborne discrete-return LIDAR data in the estimation of vertical canopy cover, angular canopy closure and leaf area index. Remote Sensing of Environment, 115(4), 1065-1080. https://doi.org/10.1016/j.rse.2010.12.011

Lefsky, M. A., Cohen, W. B., Harding, D. J., Parker, G. G., Acker, S. A., \& Gower, S. T. (2002). Lidar remote sensing of above-ground biomass in three biomes. Global Ecology and Biogeography, 11(5), 393-399. https://doi.org/10.1046/j.1466822x.2002.00303.x

Liu, J., Skidmore, A. K., Jones, S., Wang, T., Heurich, M., Zhu, X., \& Shi, Y. (2018). Large off-nadir scan angle of airborne LiDAR can severely affect the estimates of forest structure metrics. ISPRS Journal of Photogrammetry and Remote Sensing, 136, 13-25. https://doi.org/10.1016/j.isprsjprs.2017.12.004

Mitchell, B., Jacokes-Mancini, R., \& Fisk, H. (2012). United States Department of Agriculture Forest Service Remote Sensing Applications Center Geospatial Management Office Considerations for using Lidar Data-A Project Implementation Guide. December, 13.

https://www.fs.fed.us/eng/rsac/lidar_training/pdf/10032MAN1.pdf

Montaghi, A. (2013). Effect of scanning angle on vegetation metrics derived from a nationwide Airborne Laser Scanning acquisition. Canadian Journal of Remote Sensing, 39(SUPPL.1), 37-41. https://doi.org/10.5589/m13-052

Næsset, E. (2007). Airborne laser scanning as a method in operational forest inventory: Status of accuracy assessments accomplished in Scandinavia. Scandinavian Journal of Forest Research, 22(5), 433-442. https://doi.org/10.1080/02827580701672147

Næsset, E. (2009). Effects of different sensors, flying altitudes, and pulse repetition frequencies on forest canopy metrics and biophysical stand properties derived from small-footprint airborne laser data. Remote Sensing of Environment, 113(1), 148-159. https://doi.org/10.1016/j.rse.2008.09.001

Nilson, T. (1971). A theoretical analysis of the frequency of gaps in plant stands. Agricultural Meteorology, 8(C), 25-38. https://doi.org/10.1016/0002-1571(71)90092-6

Parker, G. G., \& Russ, M. E. (2004). The canopy surface and stand development: assessing forest canopy structure and complexity with near-surface altimetry. Forest Ecology and Management, 189(1-3), 307-315 https://doi.org/10.1016/j.foreco.2003.09.001 
Roussel, J. R., Béland, M., Caspersen, J., \& Achim, A. (2018). A mathematical framework to describe the effect of beam incidence angle on metrics derived from airborne LiDAR: The case of forest canopies approaching turbid medium behaviour. Remote Sensing of Environment, 209, 824-834. https://doi.org/10.1016/j.rse.2017.12.006

Singh, K. K., Chen, G., Vogler, J. B., \& Meentemeyer, R. K. (2016). When Big Data are Too Much: Effects of LiDAR Returns and Point Density on Estimation of Forest Biomass. IEEE Journal of Selected Topics in Applied Earth Observations and Remote Sensing, 9(7), 3210-3218. https://doi.org/10.1109/JSTARS.2016.2522960

Tompalski, P., White, J. C., Coops, N. C., \& Wulder, M. A. (2019). Demonstrating the transferability of forest inventory attribute models derived using airborne laser scanning data. Remote Sensing of Environment, 227, 110-124. https://doi.org/10.1016/j.rse.2019.04.006

Véga, C., Renaud, J. P., Durrieu, S., \& Bouvier, M. (2016). On the interest of penetration depth, canopy area and volume metrics to improve Lidar-based models of forest parameters. Remote Sensing of Environment, 175, 32-42. https://doi.org/10.1016/j.rse.2015.12.039

Vincent, G., Antin, C., Laurans, M., Heurtebize, J., Durrieu, S., Lavalley, C., \& Dauzat, J. (2017). Mapping plant area index of tropical evergreen forest by airborne laser scanning. A crossvalidation study using LAI2200 optical sensor. Remote Sensing of Environment, 198, 254-266. https://doi.org/10.1016/j.rse.2017.05.034

Wallace, L., Lucieer, A., Watson, C., \& Turner, D. (2012). Development of a UAV-LiDAR system with application to forest inventory. Remote Sensing, 4(6), 1519-1543. https://doi.org/10.3390/rs4061519

White, J. C., Tompalski, P., Vastaranta, M., Saarinen, N., \& Stepper, C. (2017). A model development and application guide for generating an enhanced forest inventory using airborne laser scanning data and an area-based approach. https://www.cfs.nrcan.gc.ca/pubwarehouse/pdfs/38945.pdf 